\title{
Chemical Nature of a New Antihypertensive Peptide Derived from Jellyfish
}

\author{
Yae Morinaga $^{1 *}$, Kunihisa IwaI ${ }^{1}$, Hidehiro Tomita ${ }^{2}$, Yoshiaki TaKaya ${ }^{3}$, Tetsushi NaraokA ${ }^{4}$ and Hajime Matsue ${ }^{1}$ \\ ${ }^{1}$ Graduate School of Health Sciences, Aomori University of Health and Welfare, 58-1 Mase, Hamadate, Aomori, Aomori 030-8505, \\ Japan \\ ${ }^{2}$ Shimokita Food Research Institute, Aomori Prefectural Industrial Technology Research Center, 154 Uwano, Ohata, Mutsu, Aomori \\ 039-4401, Japan \\ ${ }^{3}$ Faculty of Pharmacy, Meijo University, 150 Yagotoyama, Tempaku, Nagoya, Aichi 468-8503, Japan \\ ${ }^{4}$ Aomori Prefectural Industrial Technology Research Center, 82-9 Tanaka, Kuroishi, Aomori 036-0522, Japan
}

Received October 24, 2009; Accepted April 24, 2010

\begin{abstract}
A high-concentration (20\%) antihypertensive peptide solution with angiotensin I-converting enzyme (ACE) inhibitory activity was prepared from the powder of the jellyfish Stomolophus nomurai, a plague of which had recently hit Japan's fishing industry, using the drum dryer method. Three active fractions, Fr. 3-1, Fr. 3-3, and Fr. 3-6, were isolated from the peptide mixture by step-wise elution by Sep-Pak Vac $\mathrm{C}_{18}$ and further fractionated by high-performance liquid chromatography twice. The sequences of Fr. 3-1, Fr. 3-3, and Fr. 3-6 were determined as IGDEPLANYL, FGGIDDINQIGQSD, and YYAPFE, respectively. The most active peptide was identified with the synthetic peptide YYAPFE by sequence analysis, MALDITOF MS, and NMR spectra. Further, YYAPFQ, designed and synthesized on the basis of YYAPFE, showed the highest ACE inhibitory activity in vitro among YYAPFE, YYAPF, YYAP, YYA, and YY; however, its effect on systolic blood pressure showed a similar tendency to that of YYAPFE in spontaneously hypertensive rats.
\end{abstract}

Keywords: jellyfish, peptide, antihypertensive, drum dryer, structure, activity

\section{Introduction}

Stomolophus nomurai is a large edible jellyfish; its umbrella diameter is $>2 \mathrm{~m}$, and it weighs as much as $200 \mathrm{~kg}$. Recently, Japan's fishing industry was hit by a plague of the jellyfish. Kawamura et al. (2006) isolated 5 active antihypertensive peptides, namely QAPAQAV, PWMYY, FGVNPKYT, FTAPMN, and STKASGKL, from the protein mixture of a jellyfish, Lobonema smithi, by pepsin treatment.

However, the use of jellyfish for food and drink processing is limited because the fish contains $96.1 \%$ moisture. A peptide solution was prepared using $30 \mathrm{~g}$ of raw jellyfish in $150 \mathrm{ml}$ reaction buffer (total volume $=180 \mathrm{ml}$ ), with the jellyfish consisting of $28.8 \mathrm{~g}$ of water and $1.2 \mathrm{~g}$ of tissue. As a result, we derived only a $0.7 \%$ peptide solution from raw jellyfish. For preservation and later use, we developed a new method in which we first prepared jellyfish powder directly by using a drum dryer at $125^{\circ} \mathrm{C}$.

*To whom correspondence should be addressed.

E-mail: morinaga_yae@ym.auhw.ac.jp
In this paper, we report the preparation of a high-concentration peptide solution with antihypertensive activity from jellyfish powder and the isolation of new peptides from the hydrolysate. Furthermore, the structure and biological activities of the most active peptide and its chemically synthesized peptide derivatives were investigated by chemical analyses, ACE inhibitory activity test, and animal experiments with spontaneously hypertensive rats (SHRs).

\section{Materials and Methods}

Materials $\quad N$-Hippuryl-His-Leu hydrate, ACE from rabbit lung, and captopril were purchased from Sigma Chemical Co. (St. Louis, MO). Pepsin from porcine stomach mucosa was purchased from Wako Pure Chemical Industries Ltd. (Osaka). The synthetic peptides YYAPFE, YYAPF, YYAP, YYA, YY, and YYAPFQ were purchased from Peptide Institute Inc. (Osaka). The other reagents purchased were of analytical grade and commercially available.

ACE inhibitory activity ACE inhibitory activity assay was performed according to the methods reported by Cush- 
man and Cheung (1971), with modification. ACE solution $(100 \mathrm{mU} / \mathrm{ml})$ was preincubated with each sample $(30 \mu \mathrm{l})$ at $37^{\circ} \mathrm{C}$ for $5 \mathrm{~min}$, after which $250 \mu \mathrm{l}$ of $5 \mathrm{mM} N$-Hippuryl-HisLeu in $158 \mathrm{mM}$ borate buffer (pH 8.3) containing $400 \mathrm{mM}$ $\mathrm{NaCl}$ was added. The mixture was incubated at $37^{\circ} \mathrm{C}$ for $30 \mathrm{~min}$, and the reaction was terminated by adding $250 \mu \mathrm{l}$ of $1 \mathrm{~N} \mathrm{HCl}$. The hippuric acid produced in this reaction was extracted with ethyl acetate. An aliquot of ethyl acetate $(0.5 \mathrm{ml})$ was evaporated to dryness, and the residue was dissolved in $4 \mathrm{ml}$ of distilled water. Hippuric acid was quantified by measuring the absorbance at $228 \mathrm{~nm}$. The extent of inhibition was calculated as follows:

$$
\left\{1-\left(E_{\mathrm{S}}-E_{\mathrm{SB}}\right) /\left(E_{\mathrm{C}}-E_{\mathrm{CB}}\right)\right\} \times 100
$$

where

$E_{\mathrm{S}}=$ the optical density in the presence of ACE with ACE inhibitory component,

$E_{\mathrm{SB}}=$ the optical density in the presence of inactivated ACE with ACE inhibitory component,

$E_{\mathrm{C}}=$ the optical density in the presence of ACE, and $E_{\mathrm{CB}}=$ the optical density in the presence of inactivated ACE.

ACE inhibitory activity was expressed as $\mathrm{IC}_{50}$, which is the sample concentration that inhibits $50 \%$ of ACE activity.

Preparation of jellyfish powder Jellyfish (S. nomurai) were caught in the waters off Mutsu, Japan. The upper part of the umbrellas were cut, collected, and transported to the laboratory. The tissues obtained were washed with tap water and frozen at $-45^{\circ} \mathrm{C}$. After defrosting at $17^{\circ} \mathrm{C}$, the tissues were cut into small pieces and desalted by washing under running distilled water at $17^{\circ} \mathrm{C}$ for $15 \mathrm{~h}$. They were then ground in a blender, concentrated in vacuo at $42^{\circ} \mathrm{C}$ for $6 \mathrm{~h}$, and then drum dried at $125^{\circ} \mathrm{C}$ for $30 \mathrm{~min}$.

Preparation of peptide solution The jellyfish powder $(0.7,2.0,6.7,10.0,13.3$, and $20.0 \%)$ was digested with $1 \%$ pepsin (w/w) at $37^{\circ} \mathrm{C}$ in $75 \mathrm{ml}$ of $0.5 \mathrm{M}$ acetic acid ( $\left.\mathrm{pH} 2.47\right)$. After $24 \mathrm{~h}$, additional 1\% pepsin (w/w) was added to each solution and further incubated for $24 \mathrm{~h}$ under the same conditions as described above, by adjusting the $\mathrm{pH}$ to 2.51. After heating at $100^{\circ} \mathrm{C}$ for $10 \mathrm{~min}$, each solution was centrifuged at $13,000 \times \mathrm{g}$ at $4^{\circ} \mathrm{C}$ for $30 \mathrm{~min}$. Each supernatant was dialyzed against distilled water using a Spectra/Por membrane $(<100$ MW; Spectrum Laboratories Inc., Rancho Dominguez, CA), evaporated to dryness, and lyophilized to yield a crude peptide mixture.

\section{Purification of active peptides}

Fractionation of crude peptide mixture using Sep-Pak Vac $C_{18} \quad$ A $500 \mathrm{mg}$ aliquot of crude peptide mixture was dissolved in $25 \mathrm{ml}$ distilled water, applied to a reversedphase Sep-Pak Vac $\mathrm{C}_{18}$ column (20 cc; Waters Milford, MA, USA), and successively eluted with $25 \mathrm{ml}$ of $0.1 \%$ trifluoro- acetic acid (TFA) containing $0 \%, 20 \%$, and $40 \%$ acetonitrile $\left(\mathrm{CH}_{3} \mathrm{CN}\right)$. Each fraction was evaporated to dryness, dissolved in water, and lyophilized.

High-performance liquid chromatography (HPLC) The $40 \% \mathrm{CH}_{3} \mathrm{CN}$ fraction was dissolved in $0.1 \%$ TFA, poured into a TSK gel ODS-120T column $(\phi=4.6 \mathrm{~mm} \times 250 \mathrm{~mm}$; Tosoh, Yamaguchi, Japan) for HPLC (Shimadzu LC-10ADvp instrument, Kyoto), and eluted with a linear gradient of $20 \%$ to $40 \% \mathrm{CH}_{3} \mathrm{CN}$ in $0.1 \%$ TFA at a flow rate of $1.0 \mathrm{ml} / \mathrm{min}$ for $90 \mathrm{~min}$. Fractions obtained in 0-20, 20-30, 30-40, 40-50, 50-60, and 60-90 min were collected and named as Fr. 1, Fr. 2, Fr. 3, Fr. 4, Fr. 5, and Fr. 6, respectively. Each fraction was evaporated to dryness and lyophilized. Fr. 3 was further fractionated into 6 subfractions, Fr. 3-1, Fr. 3-2, Fr. 3-3, Fr. 3-4, Fr. 3-5, and Fr. 3-6, under the same HPLC conditions as described (Fig. 1).

Chemical composition analyses The free amino groups were determined by the ninhydrin method, using leucine (MW, 131.18) as the standard (McGrath, 1972). Amino acids were quantified using the automatic amino acid analyzer (JEOL, JLC-500, Tokyo, Japan), after hydrolysis at $110^{\circ} \mathrm{C}$ for $20 \mathrm{~h}$ in $6 \mathrm{~mol} / \mathrm{L} \mathrm{HCl}$ in a sealed tube in vacuo. Neutral hexose content was determined by the phenol-sulfuric acid method, using glucose as the standard (Dubois et al., 1956).

Determination of amino acid sequences Amino acid sequences were analyzed by the gas-phase Edman degradation method, using the protein sequencer PPSQ-10 (Shimadzu Corp., Kyoto, Japan).

Matrix-assisted laser desorption/ionization time-of-flight mass spectrometry (MALDI-TOF MS) MALDI-TOF MS was performed on a Voyager DESTR (Applied Biosystems, Foster City, CA,USA) according to the manufacturer's instructions. $\alpha$-Cyano-4-hydroxycinnamic acid was used as the matrix for the analyses. Spectrometry was performed in positive linear mode. Angiotensin I (MW, 1296.48) was

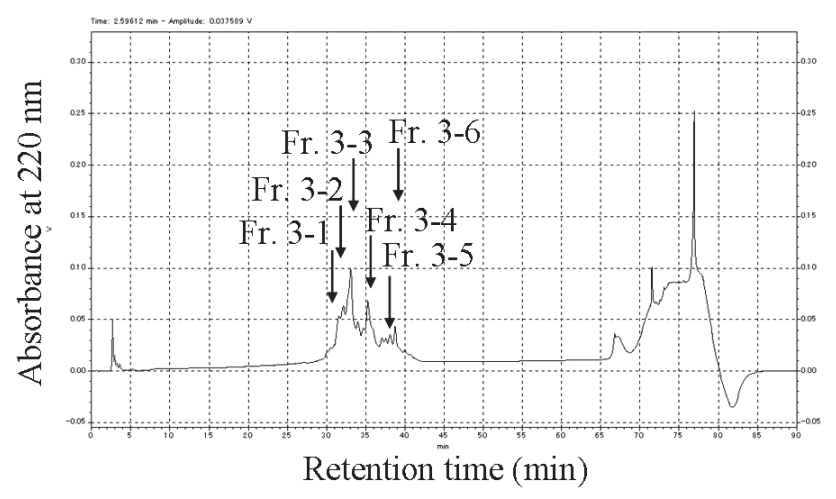

Fig. 1. Elution profile of Fr. 3. Fr. 3 was dissolved in $0.1 \%$ TFA, poured into an ODS column for HPLC and eluted with a linear gradient of $20 \%$ to $40 \% \mathrm{CH}_{3} \mathrm{CN}$ in $0.1 \%$ TFA at a flow rate of $1.0 \mathrm{ml} /$ $\mathrm{min}$ for $90 \mathrm{~min}$. 
used as an external standard for mass number (Velez et al., 2007).

500-MHz ${ }^{1} \mathrm{H}$-nuclear magnetic resonance (NMR) ${ }^{1} \mathrm{H}$ NMR spectra of Fr. 3-6, YYAPFE, and YYAPFQ were measured at $500 \mathrm{MHz}$ in $\mathrm{D}_{2} \mathrm{O}$ (JEOL JNM-ECA500) (Laussac et al., 1986). Prior to measurement, each sample was dissolved in $\mathrm{D}_{2} \mathrm{O}(99.9 \%$ and $99.996 \%$ ) (Uchisawa et al., 2007). Spectrometry was performed using acetone as the internal standard $\left(\delta=2.225 \mathrm{ppm}, 30^{\circ} \mathrm{C}\right)$.

Analysis of the tertiary structures of peptides Minimum energy contained in the tertiary structures of the active peptides (YYAPFE and YYAPFQ) was analyzed by the semiempirical molecular orbital method (MOPAC; Chem3D Ultra 7.0; Stewart, 1990).

Animals and measurement of systolic blood pressure (SBP) Male SHRs (Okamoto and Aoki, 1963), 13-wks-old, were purchased from Japan SLC Inc. (Hamamatsu, Japan). They were housed in cages under controlled conditions of $23^{\circ} \mathrm{C} \pm 2{ }^{\circ} \mathrm{C}$ and $55 \% \pm 7 \%$ humidity, with a $12 \mathrm{~h}$ light/dark cycle. They were fed a standard laboratory diet (CE-2; Clea Japan Inc., Tokyo, Japan), and distilled water was made available ad libitum.

The study was conducted in accordance with the "Guidelines for Animal Experimentation" of Aomori University of Health and Welfare.

SBP was measured by the tail-cuff method, using a blood pressure monitor (MK-1030; Muromachi Kikai, Tokyo, Japan), after having kept the SHRs in a $42^{\circ} \mathrm{C}$ warming chamber for $10 \mathrm{~min}$.

Single oral administration of $40 \% \mathrm{CH}_{3} \mathrm{CN}$ fraction and peptides to SHRs SHRs with tail SBP of $>180 \mathrm{mmHg}$ were used. Aqueous solutions of $40 \% \mathrm{CH}_{3} \mathrm{CN}$ fraction and 6 peptides (YYAPFE, YYAPF, YYAP, YYA, YY, and YYAPFQ) were orally administered only once at $250 \mathrm{mg} / \mathrm{kg}$ body weight and $3 \mathrm{mg} / \mathrm{kg}$ body weight, respectively. Captopril, administered at $20 \mathrm{mg} / \mathrm{kg}$ body weight, served as the positive control and distilled water served as the control. SBP was measured at prior to and 2, 4, 6, and $8 \mathrm{~h}$ after administration.

Data analysis The results are expressed as mean \pm standard error (SE) $(n=6)$. Statistical analyses were performed using one-way analysis of variance (ANOVA), followed by the Dunnett test.

\section{Results and Discussion}

Preparation of high-concentration antihypertensive peptide solution According to conventional methods, only a low-concentration $(0.7 \%)$ peptide solution can be prepared from raw jellyfish. Therefore, we examined the preparation of a concentrated solution from jellyfish powder, obtained using a drum dryer. The jellyfish powder yield obtained from wet tissue by the new drum dryer method was $0.11 \%$. The high-concentration (20\%) antihypertensive peptide solution prepared from the jellyfish powder showed similar ACE inhibitory activity for each amino acid concentration as the low-concentration $(0.7 \%)$ peptide solution (Table 1$)$. The drum dryer method enabled large-scale preparation of a highconcentration peptide solution with moderate ACE inhibitory activity from jellyfish powder.

Purification of active peptides A portion of the highestconcentration peptide solution was fractionated to 3 fractions by step-wise elution of $0 \%, 20 \%$, and $40 \% \mathrm{CH}_{3} \mathrm{CN}$, using Sep-Pak Vac $\mathrm{C}_{18}$ column chromatography. The $40 \%$ $\mathrm{CH}_{3} \mathrm{CN}$ fraction showed higher ACE inhibitory activity $\left(\mathrm{IC}_{50}=2.5 \mathrm{mg} / \mathrm{ml}\right)$ than the other fractions (Table 2). In order to predetermine the antihypertensive effect of the fraction showing the ACE inhibitory activity, the $40 \% \mathrm{CH}_{3} \mathrm{CN}$ fraction was orally administered to SHRs (Fig. 2). In SHRs administered captopril (20 mg/kg body weight, positive control), the SBP significantly decreased by $16.4 \pm 3.9 \mathrm{mmHg}$ $(p<0.01)$ at $4 \mathrm{~h}$ after administration. The mean SBP of the SHRs administered the $40 \% \mathrm{CH}_{3} \mathrm{CN}$ fraction $(250 \mathrm{mg} / \mathrm{kg}$ body weight) significantly decreased by $11.7 \pm 4.7 \mathrm{mmHg}$ $(p<0.05)$ and $5.0 \pm 5.2 \mathrm{mmHg}(p<0.01)$ at 4 and $8 \mathrm{~h}$ after ad-

Table 1. ACE inhibitory activity of peptide solutions from jellyfish powder with pepsin.

\begin{tabular}{ccc}
\hline $\begin{array}{c}\text { Jellyfish powder } \\
(\%)\end{array}$ & $\begin{array}{c}\text { Free amino group } \\
(\mathrm{mg})\end{array}$ & $\begin{array}{c}\mathrm{IC}_{50} \\
(\mathrm{mg} / \mathrm{ml})\end{array}$ \\
\hline 0.7 & 51.1 & 6.0 \\
2.0 & 160.0 & 5.8 \\
6.7 & 504.4 & 7.0 \\
10.0 & 807.5 & 6.1 \\
13.3 & 1170.7 & 8.3 \\
20.0 & 1526.7 & 6.2 \\
\hline
\end{tabular}

Free amino group contents were calucurated using leucine (MW, $131.18)$ as the standard. The $\mathrm{IC}_{50}$ value represents the concentration of peptide solution that inhibits $50 \%$ of ACE activity.

Table 2. Yield, chemical composition, and ACE inhibitory activity of $0 \%, 20 \%$, and $40 \% \mathrm{CH}_{3} \mathrm{CN}$ fractions obtained from jellyfish powder hydrolysate.

\begin{tabular}{ccccc}
\hline Fraction & $\begin{array}{c}\text { Yield } \\
(\%)\end{array}$ & $\begin{array}{c}\text { Neutral hexose } \\
(\%)\end{array}$ & $\begin{array}{c}\text { Amino acid } \\
(\%)\end{array}$ & $\begin{array}{c}\mathrm{IC}_{50} \\
(\mathrm{mg} / \mathrm{ml})\end{array}$ \\
\hline $0 \% \mathrm{CH}_{3} \mathrm{CN}$ & 17.3 & 2.6 & 95.3 & 9.8 \\
$20 \% \mathrm{CH}_{3} \mathrm{CN}$ & 76.1 & 5.9 & 89.2 & 5.7 \\
$40 \% \mathrm{CH}_{3} \mathrm{CN}$ & 6.6 & 3.2 & 94.2 & 2.5 \\
\hline
\end{tabular}

The experiments are described in Materials and Methods. The yield shown is that obtained from jellyfish powder hydrolysate. 


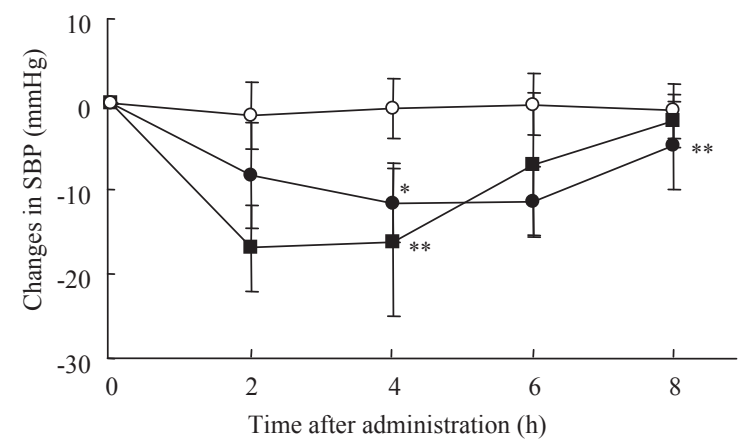

Fig. 2. Change in SBP after administration of $40 \% \mathrm{CH}_{3} \mathrm{CN}$ fraction derived from jellyfish peptides. $\bigcirc$, control; $\mathbf{\square}$, captopril $(20 \mathrm{mg} / \mathrm{kg}$ body weight); , $40 \% \mathrm{CH}_{3} \mathrm{CN}$ fraction $(250 \mathrm{mg} / \mathrm{kg}$ body weight). Each data point indicates the mean of changes in SBP of 6 SHRs, and the vertical bars represent SE. Asterisks indicate the level of significant difference from the control at each time interval. ${ }^{*} p<0.05,{ }^{*} p<<0.01$.

ministration, respectively.

The $40 \% \mathrm{CH}_{3} \mathrm{CN}$ fraction was further fractionated to 6 fractions, Fr. 1-Fr. 6, eluted with a linear gradient of $20 \%$ to $40 \% \mathrm{CH}_{3} \mathrm{CN}$ by HPLC. Fr. 3 showed the highest ACE inhibitory activity $\left(\mathrm{IC}_{50}=0.07 \mathrm{mg} / \mathrm{ml}\right)$ among all the other fractions (Table 3). This fraction was rechromatographed to yield 6 fractions, Fr. 3-1, Fr. 3-2, Fr. 3-3, Fr. 3-4, Fr. 3-5, and Fr. 3-6, by HPLC (Fig. 1). Fr. 3-1, Fr. 3-3, and Fr. 3-6, which exhibited ACE inhibitory activity, showed single peaks when applied to the same HPLC column (Table 4).

Determination of amino acid sequences of jellyfish derived peptides with ACE inhibitory activity The sequences of 3 active peptides, Fr. 3-1, Fr. 3-3, and Fr. 3-6, were analyzed by the gas-phase Edman degradation method, using a protein sequencer. Fr. 3-1 was identified as a decapeptide (IGDEPLANYL) containing -Pro-Leu-, and Fr. 3-3 was identified as a tetradecapeptide (FGGIDDINQIGQSD) rich in Gly. Fr. 3-6 was identified as a new hexapeptide (YYAPFE), which contained Tyr-Tyr- at the $\mathrm{N}$ terminus and -Phe- inside of the $\mathrm{C}$ terminus. Most of the antihypertensive peptides have been reported to contain the Pro residue at the inhibitory activity site (Cheung et al., 1980). Interestingly, Fr. 3-6 also contained Pro and was the most active among the 3 aforementioned peptides (Table 4). As compared with ACE inhibitory activity $\left(\mathrm{IC}_{50}\right)$ of FTAPMN $(0.165 \mathrm{mg} / \mathrm{ml})$ and STKASGKL $(0.350 \mathrm{mg} / \mathrm{ml})$ (Kawamura et al., 2006), the activities of the three peptides in our study were 2-6-folds.

Furthermore, the most active peptide fraction, Fr. 3-6, was identified with the synthetic peptide YYAPFE by amino acid sequence analysis, MALDI-TOF MS, and $500 \mathrm{MHz}$ ${ }^{1}$ H-NMR. In MALDI-TOF MS of Fr. 3-6, a parent ion signal appeared at $m / z 789.4308[\mathrm{M}+\mathrm{H}]^{+}$, which corresponded to the synthetic peptide YYAPFE. The main peaks in the ${ }^{1} \mathrm{H}$ -
Table 3. Yields and ACE inhibitory activities of subfractions obtained from $40 \% \mathrm{CH}_{3} \mathrm{CN}$ fraction.

\begin{tabular}{ccc}
\hline Fraction & Yield (\%) & $\mathrm{IC}_{50}(\mathrm{mg} / \mathrm{ml})$ \\
\hline Fr. 1 & 17.2 & 0.140 \\
Fr. 2 & 30.0 & 0.175 \\
Fr. 3 & 14.3 & 0.070 \\
Fr. 4 & 1.4 & - \\
Fr. 5 & 1.4 & - \\
Fr. 6 & 28.6 & 0.362 \\
\hline
\end{tabular}

The experiments are described in Materials and Methods. The yield shown is that obtained from $40 \% \mathrm{CH}_{3} \mathrm{CN}$ fraction.

Table 4. Yields and ACE inhibitory activities of subfractions obtained from Fr. 3.

\begin{tabular}{ccc}
\hline Fraction & Yield (\%) & $\mathrm{IC}_{50}(\mathrm{mg} / \mathrm{ml})$ \\
\hline Fr. 3-1 & 3.08 & 0.070 \\
Fr. 3-2 & 4.62 & 0.625 \\
Fr. 3-3 & 1.54 & 0.070 \\
Fr. 3-4 & 1.54 & 0.142 \\
Fr. 3-5 & 1.54 & 0.149 \\
Fr. 3-6 & 1.54 & 0.055 \\
\hline
\end{tabular}

The experiments are described in Materials and Methods. The yield shown is that obtained from Fr3.

NMR spectrum of Fr. 3-6 were identical with those of the synthetic peptide YYAPFE (Table 5).

Chemical nature of YYAPFE and its derivatives In order to investigate the relationship between structure and antihypertensive activities of YYAPFE and its derivatives, we designed and synthesized 6 peptides on the basis of YYAPFE. Of these 6 peptides, 5 were YYAPFE, YYAPF, YYAP, YYA, and $\mathrm{YY}$, which were designed by the deletion of one amino acid at a time from the $\mathrm{C}$ terminus of YYAPFE. YYAPFQ was synthesized by the replacement of Glu at the $\mathrm{C}$ terminus of YYAPFE with Gln. All the protons of the NMR spectra of the 6 peptides were in turn assigned to Y, YY, YYA, YYAP, YYAPF, YYAPFE, and YYAPFQ by 2D-NMR of H-H COSY. In particular, different points on the NMR spectra of YYAPFE and YYAPFQ appeared as follows.

The peak of H-4 due to - $\mathrm{CH}-$ of the Tyr residue at the N terminus of YYAPFE, a double doublet $\left(1 \mathrm{H}, J_{4-3,4-3,}=7.4\right.$ and 
Table 5. 500-MHz ${ }^{1} \mathrm{H}-\mathrm{NMR}$ data of YYAPFE and YYAPFQ in $\mathrm{D}_{2} \mathrm{O}$ at $30^{\circ} \mathrm{C}$.

\begin{tabular}{|c|c|c|c|c|c|c|c|c|c|c|c|}
\hline Peptide & Residue & Assignment & $\begin{array}{c}\delta \\
(\mathrm{ppm})\end{array}$ & Split & $J(\mathrm{~Hz})$ & Peptide & Residue & Assignment & $\begin{array}{c}\delta \\
(\mathrm{ppm})\end{array}$ & Split & $J(\mathrm{~Hz})$ \\
\hline \multirow[t]{25}{*}{ YYAPFE } & $\mathrm{Y}$ & $1,1^{\prime}, 1^{\prime \prime}, 1^{\prime \prime \prime}$ & 6.829 & $\mathrm{dd}$ & $8.5,9.5$ & YYAPFQ & Y & $1,1^{\prime}, 1^{\prime \prime}, 1^{\prime \prime \prime}$ & 6.814 & $\mathrm{dd}$ & 8.5 \\
\hline & & $2,2^{\prime}, 2^{\prime \prime}, 2^{\prime \prime \prime}$ & 7.084 & $\mathrm{dd}$ & $8.5,9.5$ & & & $2,2^{\prime}, 2^{\prime \prime}, 2^{\prime \prime \prime}$ & 7.076 & $\mathrm{dd}$ & 8.5 \\
\hline & & $3,3^{\prime}$ & 3.141 & dd & $7.4,7.9,13.0$ & & & 3 & 3.089 & $\mathrm{dd}$ & $7.9,13.0$ \\
\hline & & 3", 3", & 2.896 & dd & $7.6,7.7,14.0$ & & & $3^{\prime}$ & 2.988 & $\mathrm{dd}$ & $7.4,13.0$ \\
\hline & & 4 & 4.169 & $\mathrm{dd}$ & $7.4,7.9$ & & & 3", 3"’ & 2.883 & $\mathrm{dd}$ & $7.6,7.7,14.0$ \\
\hline & & $4^{\prime}$ & 4.513 & $\mathrm{dd}$ & $7.6,7.7$ & & & 4 & 4.077 & $\mathrm{dd}$ & $7.4,7.9$ \\
\hline & & & & & & & & $4^{\prime}$ & 4.504 & $\mathrm{dd}$ & $7.6,7.7$ \\
\hline & A & 5 & 4.447 & $\mathrm{q}$ & 6.8 & & A & 5 & 4.439 & $\mathrm{q}$ & 6.8 \\
\hline & $\mathrm{P}$ & $6,6^{\prime}$ & 3.491 & $\mathrm{~m}$ & $6.5,13.4$ & & $\mathrm{P}$ & 6,6 & 3.507 & $\mathrm{~m}$ & $6.5,13.4$ \\
\hline & & $7,7^{\prime}$ & 1.932 & $\mathrm{~m}$ & $6.5,7.1,12.3$ & & & $7,7^{\prime}$ & 1.909 & $\mathrm{~m}$ & $6.5,7.1,12.3$ \\
\hline & & 8 & 2.179 & $\mathrm{~m}$ & $5.7,7.1$ & & & 8 & 2.172 & $\mathrm{~m}$ & $5.7,7.1$ \\
\hline & & $8^{\prime}$ & 1.801 & $\mathrm{~m}$ & $5.9,7.1$ & & & $8^{\prime}$ & 1.773 & $\mathrm{~m}$ & $5.9,7.1$ \\
\hline & & 9 & 4.262 & $\mathrm{dd}$ & $5.7,5.9$ & & & 9 & 4.270 & $\mathrm{dd}$ & $5.7,5.9$ \\
\hline & $\mathrm{F}$ & 10 & 4.627 & $\mathrm{dd}$ & $5.9,8.3$ & & F & 10 & 4.604 & $\mathrm{dd}$ & $5.9,8.3$ \\
\hline & & $11,11^{\prime}$ & 3.039 & $\mathrm{dd}$ & $5.9,8.3,13.0$ & & & 11 & 3.178 & $\mathrm{dd}$ & $8.3,13.0$ \\
\hline & & $12,12^{\prime}$ & 7.226 & $\mathrm{~d}$ & $7.1,7.4$ & & & $11^{\prime}$ & 3.089 & $\mathrm{dd}$ & $5.9,13.0$ \\
\hline & & $13,13^{\prime}$ & 7.364 & $\mathrm{dd}$ & $7.1,7.4$ & & & $12,12^{\prime}$ & 7.276 & $\mathrm{~d}$ & $7.1,7.4$ \\
\hline & & 14 & 7.299 & $\mathrm{dd}$ & 7.1 & & & $13,13^{\prime}$ & 7.367 & $\mathrm{dd}$ & $7.1,7.4$ \\
\hline & & & & & & & & 14 & 7.310 & $\mathrm{dd}$ & 7.1 \\
\hline & $\mathrm{E}$ & 15 & 4.132 & $\mathrm{dd}$ & $4.8,4.9$ & & Q & 15 & 4.133 & $\mathrm{dd}$ & $4.8,4.9$ \\
\hline & & 16 & 2.179 & $\mathrm{~m}$ & $4.9,5.9,12.8$ & & & 16 & 2.172 & $\mathrm{~m}$ & $4.9,5.9,12.8$ \\
\hline & & $16^{\prime}$ & 1.873 & $\mathrm{~m}$ & $4.8,7.4,12.8$ & & & $16^{\prime}$ & 1.909 & $\mathrm{~m}$ & $4.8,7.4,12.8$ \\
\hline & & 17 & 2.179 & $\mathrm{~m}$ & $5.9,13.9$ & & & 17 & 2.172 & $\mathrm{~m}$ & $5.9,13.9$ \\
\hline & & $17^{\prime}$ & 2.025 & $\mathrm{~m}$ & $7.4,13.9$ & & & $17^{\prime}$ & 2.057 & $\mathrm{~m}$ & $7.4,13.9$ \\
\hline & A & $\mathrm{CH}_{3}$ & 1.254 & d & 6.8 & & A & $\mathrm{CH}_{3}$ & 1.255 & d & 6.8 \\
\hline
\end{tabular}

Fr. 3-6 obtained from jellyfish was identified with the synthetic peptide YYAPFE by sequence analysis, MALDI-TOF MS, and NMR. The number of protons for YYAPFE and YYAPFQ is shown in Fig. 3. Chemical shifts of ${ }^{1} \mathrm{H}-\mathrm{NMR}$ were determined using acetone (2.225 ppm) as the internal standard.

$7.9 \mathrm{~Hz}$ ) at $\delta=4.169 \mathrm{ppm}$ (Fig. 3), appeared at a lower field than that of YYAPFQ, a double doublet $\left(1 \mathrm{H}, J_{4-3}, 4-3=7.4\right.$ and $7.9 \mathrm{~Hz}$ ) at $\delta=4.077 \mathrm{ppm}$. The peak of $\mathrm{H}-3$ and $\mathrm{H}-3$ ' due to $-\mathrm{CH}_{2}-$ of the Tyr residue at the $\mathrm{N}$ terminus of YYAPFE, a double doublet $\left(2 \mathrm{H}, J_{4-3,4-3^{3}, 3-3^{3}}=7.4,7.9\right.$, and $\left.13.0 \mathrm{~Hz}\right)$ at $\delta=3.141 \mathrm{ppm}$ (Fig. 3), appeared at a lower field than that of YYAPFQ, 2 double doublets $\left(2 \mathrm{H}, J_{4-3,3-3},=7.9\right.$ and $13.0 \mathrm{~Hz}, J_{4-3^{\prime}, 3-3^{\prime}}=7.4$ and $\left.13.0 \mathrm{~Hz}\right)$ at $\delta=3.089 \mathrm{ppm}$ and $\delta$ $=2.988 \mathrm{ppm}$, respectively. The peak of $\mathrm{H}-11$ and $\mathrm{H}-11$ ' due to $-\mathrm{CH}_{2}-$ of the Phe residue of YYAPFE, a double doublet $\left(2 \mathrm{H}, J_{10-11,10-11}, 11-11,=5.9,8.3\right.$, and $\left.13.0 \mathrm{~Hz}\right)$ at $\delta=3.039 \mathrm{ppm}$ (Fig. 3), appeared at a higher field than that of YYAPFQ, 2 double doublets $\left(2 \mathrm{H}, J_{10-11,11-11}=8.3\right.$ and $13.0 \mathrm{~Hz}, J_{10-11}$, 11-11 $=5.9$ and $13.0 \mathrm{~Hz}$ ) at $\delta=3.178 \mathrm{ppm}$ and $\delta=3.089 \mathrm{ppm}$, respectively. From the above results, it appears that YYAPFE and YYAPFQ have different stereochemistry, originating from the space distance between $-\mathrm{CH}_{2}-\mathrm{CH}$ - of $\mathrm{N}$ terminus
Tyr and $-\mathrm{CH}_{2}-\mathrm{CH}$ - of $\mathrm{C}$ terminal Phe.

Biological activities of synthetic YYAPFE and its peptide derivatives in vitro and in vivo

$A C E$ inhibitory activities of synthetic YYAPFE and its peptide derivatives in vitro We attempted to design a more potent antihypertensive peptide than the natural peptide. We examined the ACE inhibitory activities of synthetic YYAPFE and the peptides synthesized by deleting one amino acid at a time from the $\mathrm{C}$ terminus of YYAPFE, i.e., YYAPF, YYAP, YYA, and YY, along with YYAPFQ, which was synthesized by the replacement of Glu at the $\mathrm{C}$ terminus of YYAPFE with Gln (Table 6). The peptides were converted to the acetate form by acetic anion-exchange resin column chromatography, as general synthetic peptides are synthesized in the trifluoroacetate form. ACE inhibitory activities increased in the following order: YYAPF $<$ YYAPFE $<$ YYA $<$ YYAP $<$ YY $<$ YYAPFQ. Shorter peptides than YYAPFE in Table 6 

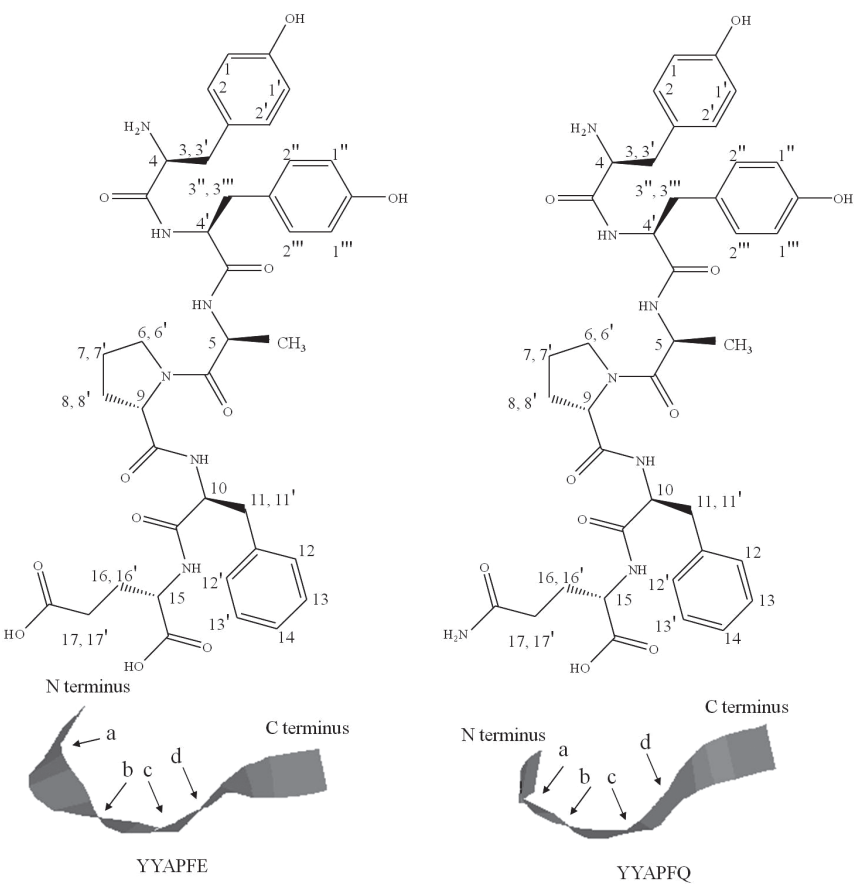

Fig. 3. Structural formulae and ribbon structures of YYAPFE and YYAPFQ. The protons in each residue were numbered in order to assign NMR spectra to both peptides. a, b, c and d show the twist points in both the peptides. The experiment has been described in Materials and Methods.

Table 6. ACE inhibitory activities of the 6 synthetic peptides.

\begin{tabular}{cc}
\hline Synthetic peptide & $\mathrm{IC}_{50}(\mathrm{mM})$ \\
\hline YY & 0.68 \\
YYA & 2.80 \\
YYAP & 2.33 \\
YYAPF & 4.35 \\
YYAPFE & 3.77 \\
YYAPFQ & 0.46 \\
\hline
\end{tabular}

Fr.3-6 from jellyfish was identified using the synthetic peptide YYAPFE, by sequencing analysis, MALDI-TOF MS, and NMR spectroscopy. Four synthetic peptides were designed by the deletion of 1 amino acid at a time from the $C$ termini of YYAPFE, YYAPF, YYAP, YYA, and YY. YYAPFQ was synthesized by the replacement of Glu at the $\mathrm{C}$ terminus of YYAPFE with Gln. The experiment has been described in Materials and Methods.

tended to exhibit higher activity; however, YYAPFQ showed the highest activity among the 6 peptides. We assumed that short peptides were different from ACE inhibitory pattern of long peptides.

Furthermore, we found that the activity increased 8-fold when Glu at the $\mathrm{C}$ terminus of YYAPFE was replaced with Gln. Differences with respect to the presence of a carboxyl group or an amide group at the $\mathrm{C}$ termini of the peptides influenced their structures and biological activities signifi-

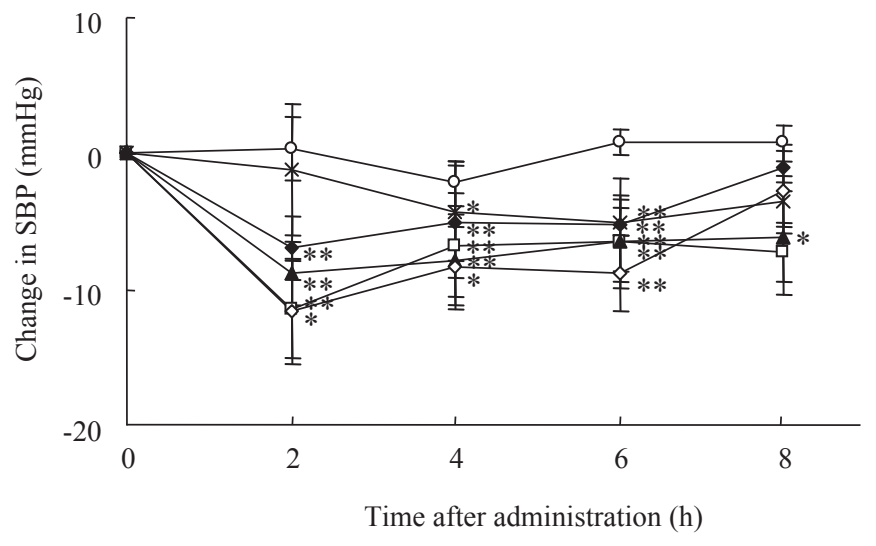

Fig. 4. Changes in SBP after administration of synthetic peptides. $\bigcirc$ : control, $\square$ : YYAPFE, $\mathbf{\Delta}$ : YYAPF, $\times$ : YYAP, $\diamond$ : YYA, $\diamond$ : YY. Dose is $3 \mathrm{mg}$ of peptide/ $\mathrm{kg}$ body weight. Each data point represents the mean of changes in the SBP of 6 SHRs, and the vertical bars represent the SE. The asterisks indicate the level of significant difference from the control at each time interval. $*: p<0.05, * *: p<0.01$.

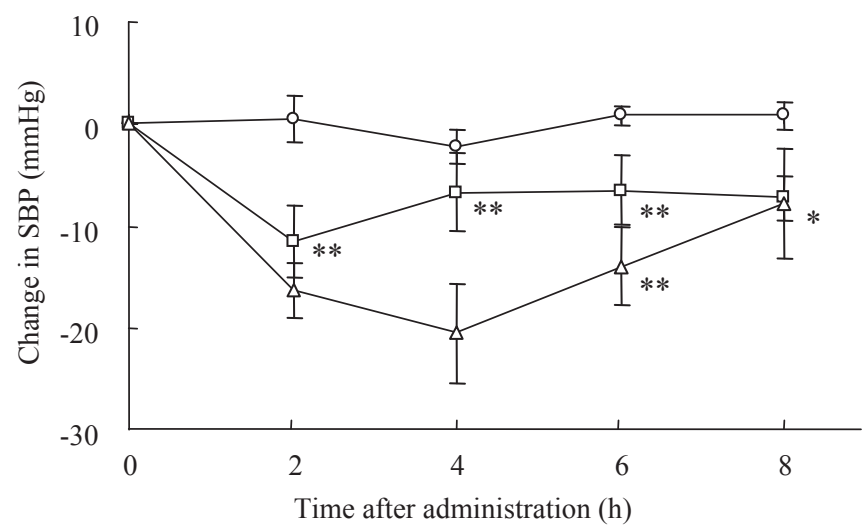

Fig. 5. Changes in SBP after administration of YYAPFE and YYAPFQ. $\bigcirc$ : control, $\square$ : YYAPFE, $\triangle$ : YYAPFQ. Dose is $3 \mathrm{mg}$ of peptide/kg body weight. Each point represents the mean of the changes in the SBP of the 6 SHRs, and the vertical bars represent the SE. Asterisks indicate the level of significant difference from the control at each time interval. *: $p<0.05, * *: p<0.01$.

cantly.

Antihypertensive effects of synthetic YYAPFE and its peptide derivatives on SHRs in vivo To confirm the experimental observations in vitro, we examined the antihypertensive activities of the 5 synthetic peptides YYAPFE, YYAPF, YYAP, YYA, and YY by oral administration to SHRs. As shown in Fig. 4, the activities of the 5 synthetic peptides YYAPFE, YYAPF, YYAP, YYA, and YY, with the latter 4 designed on the basis of YYAPFE, showed antihypertensive effects. Blood pressure was significantly decreased 2, 4 and $6 \mathrm{~h}$ after administration of YYAPFE, YYA and YY; 2, 4, 6 and $8 \mathrm{~h}$ after administration of YYAPF; and 4 and $6 \mathrm{~h}$ after administration of YYAP, respectively. Since SBP in rats given YYAPF significantly decreased at all times after admin- 
istration, it was assumed that YYAPF was the most effective of the short peptides designed based on YYAPFE.

These results were supported by the observation that the jellyfish powder-derived $40 \% \mathrm{CH}_{3} \mathrm{CN}$ fraction also showed a similar type of antihypertensive effect as with YYAPFE and its short peptides.

Effect of Glu or Gln present at the C terminus of YYAPFE on the SBP of SHRs after single oral administration We investigated whether the antihypertensive activity and continuous effect of YYAPFE on the SBP of SHRs, after single oral administration, was altered by replacing Glu at the $\mathrm{C}$ terminus of YYAPFE with Gln (YYAPFQ). YYAPFE and YYAPFQ showed large differences in their ACE inhibitory activities in vitro (Table 6). Blood pressure was significantly decreased 6 and $8 \mathrm{~h}$ after YYAPFQ administration. YYAPFE showed similar antihypertensive activity and continuous effect on SBP as observed with YYAPFQ in vivo (Fig. 5).

Difference in the tertiary structures of YYAPFE and $Y Y A P F Q$ Since the biological activities of YYAPFE and YYAPFQ in vitro and in vivo differed, we examined the differences in the tertiary structures of the 2 peptides. We compared the ribbon structures of YYAPFE and YYAPFQ by analyzing the minimum energy contained in their tertiary structures using MOPAC. As shown in Fig. 3, the analysis showed that differences with respect to the presence of a carboxyl group or an amide group at the $\mathrm{C}$ termini of the 2 peptide structures affected their tertiary structures and biological properties, as observed in their NMR spectra (Table 5). From the results, we inferred that both peptides contained 4 twist points of a, b, c, and d, and the distance between a and $d$ in YYAPFQ was shorter than that in YYAPFE. Additionally, the structure of angiotensin II, determined by MOPAC, contained similar twist points and deep cleft structure presented in the ACE active site (Riordan, 2003). We speculated that these twists and curve structure, and the distance between $\mathrm{N}$ and $\mathrm{C}$ terminus in two peptides were important in ACE inhibitory activity.

Jellyfish contains $96.1 \%$ water, $0.40 \%$ proteins, $0.58 \%$ carbohydrates, $0.02 \%$ fats, and $2.90 \%$ minerals. In order to utilize jellyfish, we resolved the issue of high water content by using the drum dryer method, and prepared a high-concentration peptide solution containing several antihypertensive peptides from the jellyfish protein mixture. We isolated 3 antihypertensive peptides and one of them, YYAPFE, exhibited a continuous type of antihypertensive activity in vivo. Ultimately, we prepared a peptide of greater potential, YYAPFQ, which was based on the natural peptide YYAPFE. Thus far, most studies on jellyfish have focused on collagen, which is the main protein in jellyfish; for example, the effects of its immunostimulatory (Song et al., 2006, Suga- hara et al., 2006, Nishimoto et al., 2008) and cell adhesion properties (Schmid and Bally, 1988, Frank and Rinkevich, 1999, Schmid et al., 1999) have been studied. Collagen has a characteristic triple-helical conformation that is derived from the $[\mathrm{Gly}-\mathrm{X}-\mathrm{Y}]_{\mathrm{n}}$ sequence (Bornstein and Byers, 1981). However, YYAPFE does not contain Gly, and the amino acid composition of $40 \% \mathrm{CH}_{3} \mathrm{CN}$ fraction from which YYAPFE was obtained is similar to that of the non-collagenous protein (Miura and Kimura, 1985) obtained from the jellyfish, even though the $40 \% \mathrm{CH}_{3} \mathrm{CN}$ fraction contained IGDEPLANYL and FGGIDDINQIGQSD (data not shown). Therefore, we presumed the non-collagenous protein to be the precursor of YYAPFE. Our study contributes to the utilization of jellyfish as a raw material for the production of functional foods and drinks having antihypertensive activities.

Acknowledgements This study was supported in part by a Grant from the Special Research Fund for Academic Research at Aomori University of Health and Welfare, Japan.

\section{References}

Bornstein, P. and Byers, P.H. (1981). Physical structure of the collagens. In "Collagen Metabolism", The Upjohn Company, Michigan, pp. 8-10.

Cheung, H.S., Wang, F.L., Ondetti, M.A., Sabo, E.F. and Cushman, D.W. (1980). Binding of peptide substrates and inhibitors of angiotensin-converting enzyme. Importance of the $\mathrm{COOH}$-terminal dipeptide sequence. J. Biol. Chem., 255, 401-407.

Cushman, D.W. and Cheung, H.S. (1971). Spectrophotometric

assay and properties of the angiotensin-converting enzyme of rabbit lung. Biochem. Pharmacol., 20, 1637-1648.

Dubois, M., Gilles, K.A., Hamilton, J.K., Rebers, P.A. and Smith, F. (1956). Colorimetric method for determination of sugars and related substances. Anal. Chem., 28, 350-356.

Frank, U. and Rinkevich, B. (1999). Scyphozoan jellyfish's mesoglea supports attachment, spreading and migration of anthozoans' cells in vitro. Cell Biol. Int., 23, 307-311.

Kawamura, Y., Higashimura, T., Nakayama, T. and Ushita, T. (2006). New peptides from jellyfish protein and the utilization. Japan Kokai Tokkyo Koho, 265241. Oct. 5.

Laussac, J.P., Cung, M.T., Pasdeloup, M., Haran, R., Marraud, M., Lefrancier, P., Dardenne, M. and Bach, J.F. (1986). NMR study of thymulin, a lymphocyte differentiating thymic nonapeptide. Conformational states of free peptide in solution. J. Biol. Chem., 261, 7784-7790.

McGrath, R. (1972). Protein measurement by ninhydrin determination of amino acids released by alkaline hydrolysis. Anal. Biochem., 49, 95-102.

Miura, S. and Kimura, S. (1985). Jellyfish mesogloea collagen. Characterization of molecules as alpha 1 alpha 2 alpha 3 hetero- 
trimers. J. Biol. Chem., 260, 15352-15356.

Nishimoto, S., Goto, Y., Morishige, H., Shiraishi, R., Doi, M., Akiyama, K., Yamauchi, S. and Sugahara, T. (2008). Mode of action of the immunostimulatory effect of collagen from jellyfish. Biosci. Biotechnol. Biochem., 72, 2806-2814.

Okamoto, K. and Aoki K. (1963). Development of a strain of spontaneously hypertensive rats. Jpn. Circ. J., 27, 282-293.

Riordan, J.F. (2003). Angiotensin-I-converting enzyme and its relatives. Genome Biol., 4, 225.

Schmid, V. and Bally, A. (1988). Species specificity in cell-substrate interactions in medusae. Dev. Biol., 129, 573-581.

Schmid, V., Ono, S.I. and Reber-Müller, S. (1999). Cell-substrate interactions in cnidaria. Microsc. Res. Tech., 44, 254-268.

Song, E., Yeon, Kim, S., Chun, T., Byun, H.J. and Lee, Y.M. (2006). Collagen scaffolds derived from a marine source and their bio- compatibility. Biomaterials, 27, 2951-2961.

Stewart, J.J.P. (1990). MOPAC: A general molecular orbital package. Quant. Chem. Prog. Exch., 10, 86.

Sugahara, T., Ueno, M., Goto, Y., Shiraishi, R., Doi, M., Akiyama, K. and Yamauchi, S. (2006). Immunostimulation effect of jellyfish collagen. Biosci. Biotechnol. Biochem., 70, 2131-2137.

Uchisawa, H., Naraoka, T. and Ono T. (2007). A novel ornithinecontaining tripeptide isolated from the extract of the brackishwater bivalve Corbicula japonica. Biochim. Biophys. Acta, 1770, 790-796.

Velez, J.C., Bland, A.M., Arthur, J.M., Raymond, J.R. and Janech, M.G. (2007). Characterization of renin-angiotensin system enzyme activities in cultured mouse podocytes. Am. J. Physiol. Renal Physiol., 293, 398-407. 